\title{
Siderophore production by Bacillus subtilis MF497446 and Pseudomonas koreensis MG209738 and their efficacy in controlling Cephalosporium maydis in maize plant
}

\author{
Nasr Ghazy ${ }^{1}$ - Sahar El-Nahrawy ${ }^{2}$ (I) \\ Received: 15 July 2020 / Revised: 7 October 2020 / Accepted: 1 November 2020 / Published online: 24 November 2020 \\ (c) Springer-Verlag GmbH Germany, part of Springer Nature 2020
}

\begin{abstract}
Late wilt disease, caused by Cephalosporium maydis in maize plant, is one of the main economical diseases in Egypt. Therefore, to cope with this problem, we investigated the potentiality of plant growth promoting rhizobacteria in controlling this disease. Six strains (Bacillus subtilis, B. circulance, B. coagulanse, B. licheniformis, Pseudomonas fluroscence and $P$. koreensis) were screened for siderophore production, and using dual plate culture method and greenhouse experiment, antagonistic activity against $C$. maydis was studied. Using two superior strains, single and dual inoculation treatments in maize were applied in field experiment during the 2018 and 2019 seasons. Results indicated that B. subtilis and $P$. koreensis strains had shown the most qualitative and quantitative assays for siderophore production and antagonistic activities. In greenhouse, the most effective treatments on the pre- and post-emergence damping off as well as growth promotion of maize were T3 treatment (inoculated with B. subtilis), and T8 treatment (inoculated with $P$. koreensis). In field experiment, T5 treatment (inoculated with a mixture of $B$. subtilis and $P$. koreensis) showed significant increases in catalase (CAT), peroxidase (POX) and polyphenol oxidase (PPO) activities, as well as total chlorophyll and carotenoids than control treatments during the two growing seasons. In the same way, the highest effect in reducing infection and increasing the thickness of the sclerenchymatous sheath layer surrounding the vascular bundles in maize stem was observed and these results were a reflection of the increase in yield and yield parameters.
\end{abstract}

Keywords Late wilt disease $\cdot$ Maize $\cdot$ Siderophore production $\cdot$ PGPR $\cdot$ Antioxidant enzymes $\cdot$ Stem histological differences

Communicated by Erko Stackebrandt.

Electronic Supplementary Material The online version of this article (https://doi.org/10.1007/s00203-020-02113-5) contains supplementary material, which is available to authorized users.

Sahar El-Nahrawy

sahar.elnahrawy@yahoo.com

1 Maize and Sugar Crops Dis. Department, Plant Pathology Research Institute, Agricultural Research Center, Giza, Egypt

2 Department of Agricultural Microbiology, Soils, Water and Environment Research Institute, Agricultural Research Center, Giza, Egypt

\section{Introduction}

Maize (Zea mays L.) is one of the most important cereal crops for nutrition in the global population and is a source of protein and micronutrients (Nuss and Tanumihardjo, 2010; Zhao et al. 2020). In Egypt, harvested has reached about 935,778 ha for that production quantity 7.3 million tons of grains (FAOSTST 2018). Worldwide, diseases on maize plants lead to detrimental effects on the economy and the food supplies and pose serious health hazards to both humans and animals. One of these fungal diseases in maize is late wilt, caused by Cephalosporium maydis, which is one of the main economical diseases in Egypt (Samra et al. 1963), and the infection incidence leads to decrease in grain yield to $40 \%$ (Labib et al. 1975). This pathogen enters tissue from root and colonizes the xylem (Sabet et al. 1970), and during tasseling formation stage, late wilt disease appears in 
leaves and then develops into stalks (El-Shafey and Claflin 1999).

To protect against soilborne diseases, it is better to use chemical pesticides in controlling these diseases but, these are expensive as well as not environmental friendly. So, many researchers have used plant growth-promoting rhizobacteria (PGPR) as biological control against late wilt disease associated with the maize rhizosphere which could improve plant health, reduce chemical pesticides, and develop efficient biological control strategies (El-Mehalowy et al. 2004 and Ashour et al. 2013; Omara et al. 2017, 2018). Therefore, recently, biological control by PGPR has been adopted on a commercial scale by using a number of experimental approaches. These microorganisms can be found in the rhizosphere, rhizoplane or in association with roots, which improve plant growth promotion in the absence of pathogens (direct mechanism) or reduce the deleterious effects of pathogens on crop yield (indirect mechanism) by antibiosis, HCN production, competition, induced systemic resistance and siderophore production (Shivakumar 2007; Mohammed et al. 2020; Larkin 2020).

Siderophore production by microorganisms has received great attention due to their application in different branches of the agriculture sector such as soil science, plant pathology and environmental sciences. Siderophores are organic compounds with low molecular weight $(<10 \mathrm{kDa})$ and high specific affinity to chelate iron (Oswald 2010). On the other hand, there are four groups of siderophores produced by bacteria (catecholates, hydroxamates, salicylate and carboxylates) (Rajkumar et al. 2010), which play a vital role in the accumulation of iron from different organic materials. Common genera of siderophore-producing bacteria are Rhizobium, Arthrobacter, Azospirillum, Pseudomonas, Azotobacter, Bacillus Acinetobacter, Alcaligenes, Beijerinckia, Burkholderia and Enterobacter (Bashan et al. 2014; Ghavami et al. 2016; Grobelak and Hiller 2017; El-Nahrawy et al. 2019; Sinha and Parli 2020).

Previously, some studies have reported the role of siderophores in the suppression of Pythium species and enhancement of the growth of wheat by P. fluorescent (Becker and Cook 1988). Also, pyoverdin production by $P$. aeruginosa 7 NSK 2 was able to increase the yield of barley, wheat, maize, cucumber and spinach (Hofte et al. 1991). Suryakala et al. (2004) suggested that trihyobroxamate type pyoverdines of siderophores forming hexadentate ligands with $\mathrm{Fe}^{+3}$ ions. These siderophores might be exploited as potent biocontrol compounds against plant pathogens.

Lately, most studies support the siderophore theory of biological control by PGPR. López-Reyes et al. (2017) showed that $A$. brasilense, isolated from teosinte (Zea mays L. ssp. mexicana), produced bacterial metabolites such as siderophores and indoles which are used in the suppression of Alternaria, Bipolaris and Fusarium as well as increase the biomass of maize plants under greenhouse and field conditions. Sheng et al. (2020). showed that Brevibacillus brevis GZDF3 (PGPR strain) isolated from the rhizosphere soil of Pinellia ternate could produce siderophores with strong antagonistic activity to Candida albicans. Also, P. aeruginosa and $P$. fluorescens strains could be used to develop active biocontrol agents of tomato bacterial wilt caused by Ralstonia solanacearum (Mohammed et al. 2020).Similarly, Larkin (2020) suggested that bacterial inoculation with $B$. subtilis GB03 can be used as biocontrol against two strains of Rhizoctonia (Rhs1A1 and Bs69) under organic production practices over three field seasons.

The purpose of this research was to evaluate some strains of PGPR to siderophore production, and their ability to control late wilt disease, growth promotion and yield of maize plant under laboratory, greenhouse and field conditions.

\section{Materials and methods}

\section{Microorganisms and growth conditions}

Six bacterial strains, Bacillus subtilis MF497446, B. circulance NCAIM B.02324, B. coagulanse NCAIM B.01123, $B$. licheniformis Sh8, Pseudomonas fluroscence SARS 5 and $P$. koreensis MG209738, were used in the present study. These were obtained from Bacteriology Laboratory, Sakha Agricultural Research Station, Kafr El-Sheikh, Egypt. All bacterial strains were maintained on Nutrient Broth (NB) medium containing $\left(\mathrm{g} \mathrm{l}^{-1}\right)$ : peptone 5.0, beef extract 3.0, $\mathrm{NaCl} 5.0$, pH 6.8-7.2 (Anonymous 1957).

On the other hand, Cephalosporium maydis fungi were obtained from Maize and Sugar Crops Dis. Dept., Plant Pathol. Res. Inst., Agric. Res. Center, Giza, Egypt. C. maydis was grown on potato dextrose medium supplemented with $0.2 \%$ yeast extract (Yassin 2000).

\section{Evaluation of siderophore production}

The production process of siderophore depends on the preparation of the cell growth medium that is sufficiently Fe deficient. So, all glassware used was washed in acid (e.g., $6 \mathrm{M} \mathrm{HCl}$ ) overnight then rinsed thoroughly in distilled water and sterilized by autoclaving before use. The siderophore production capability of tested strains was evaluated by both qualitative and quantitative methods. Also, detection of siderophore production by Arnow's, Csáky and $\mathrm{FeCl}_{3}$ tests was determined.

\section{Qualitative assay}

Chrome azurol sulfonate (CAS) agar plate method (Schwyn and Neilands 1987) was performed for qualitative assay 
siderophore production. Briefly, all tested strains were grown in Nutrient Broth medium for $48 \mathrm{~h}$ on a rotary shaker $(120 \mathrm{rpm})$ at $30{ }^{\circ} \mathrm{C}$ and then $0.05 \mathrm{ml}$ of the resultant bacterial suspension containing $9 \times 10^{8}$ cells ml ${ }^{-1}$ was spotted over CAS-agar plates in triplicate and incubated for 5 days at $30^{\circ} \mathrm{C}$. On CAS blue agar, an orange halo formed around colonies which indicates the ability of the bacterial strains to produce siderophore. The size of the halo diameter/colony diameter ratios were screened and the results are shown as the mean \pm standard deviation (SD).

\section{Quantitative assay}

In culture supernatant extracts, CAS solution was used to quantify siderophore activity (Schwyn and Neilands 1987). So, all tested strains were grown in a Nutrient Broth medium for $48 \mathrm{~h}$ on a rotary shaker $(120 \mathrm{rpm})$ at $30^{\circ} \mathrm{C}$ and then centrifuged for $15 \mathrm{~min}$ at $3000 \mathrm{rpm} .0 .5 \mathrm{ml}\left(9 \times 10^{8} \mathrm{cells} \mathrm{ml}^{-1}\right)$ of the supernatant was mixed with $0.5 \mathrm{ml}$ CAS solution and $10 \mu \mathrm{l}$ shuttle solution (sulfosalicylic acid). After $2 \mathrm{~h}$ of incubation at room temperature, the absorbance of the mixture was read using UV/Vis SPECTROPHOTOMETER (Bibby Scientific Ltd, Dunmow, Essex. UK, Model 6705) at $630 \mathrm{~nm}$. Simultaneously, the reference samples (blank) were prepared with Nutrient Broth medium, CAS solution, and shuttle solution. The percentage of siderophore was estimated using the following formula:

$(\mathrm{Ar}-\mathrm{As}) / \mathrm{Ar} \times 100$,

where $\mathrm{Ar}$ is the absorbance at $630 \mathrm{~nm}$ of the reference, and As is the absorbance at $630 \mathrm{~nm}$ of the samples. Experiment was performed in triplicate, and the results are shown as the mean \pm standard deviation (SD).

\section{Arnow's assays}

Arnow's assays was used to confirm catecholate siderophore production (Arnow 1937; Lacava et al. 2008). The culture supernatants obtained from quantitative assay were subjected to determine. $3 \mathrm{ml}$ of the culture supernatant was then mixed with $0.3 \mathrm{ml}$ of $5 \mathrm{~N} \mathrm{HCl}$ solution, $1.5 \mathrm{ml}$ of Arnow's reagent $\left(10 \mathrm{~g} \mathrm{NaNO}_{2}, 10 \mathrm{~g} \mathrm{Na}_{2} \mathrm{MoO}_{4} \cdot 2 \mathrm{H}_{2} \mathrm{O}\right.$ dissolved in $50 \mathrm{ml}$ distilled water) and $0.3 \mathrm{ml}$ of $10 \mathrm{~N} \mathrm{NaOH}$. Then the mixture was incubated for $10 \mathrm{~min}$ to complete the reaction in which the presence or absence of pink colour was observed.

\section{Csáky test}

Csáky test was used for assay of hydroxamate siderophore production Cśaky (1948). One milliliter of sample culture broth with $1 \mathrm{ml}$ of $\mathrm{H}_{2} \mathrm{SO}_{4}(6 \mathrm{M})$ was mixed and autoclaved for $30 \mathrm{~min}$ at $121{ }^{\circ} \mathrm{C}$. Upon cooling, $1 \mathrm{ml}$ of sulfanilic acid
$(1 \% \mathrm{w} / \mathrm{v})$ prepared in acetic acid $30 \%(\mathrm{v} / \mathrm{v})$ with $0.5 \mathrm{ml}$ iodine $(1.3 \% \mathrm{w} / \mathrm{v})$ was mixed and this mixture was incubated for $5 \mathrm{~min}$ at room temperature. Further, excess iodine was removed by adding $1 \mathrm{ml}$ of trisodium arsenite $\left(\mathrm{Na}_{3} \mathrm{AsO}_{2}\right)$ $(2 \% \mathrm{w} / \mathrm{v})$ prepared in water. Finally, $1 \mathrm{ml}$ solution of $\alpha$-naphthylamine $(0.3 \% \mathrm{w} / \mathrm{v})$ prepared in acetic acid $30 \%$ $(\mathrm{v} / \mathrm{v})$ was added to the solution resulting in change of color from orange to red.

\section{$\mathrm{FeCl}_{3}$ test}

According to Arnow (1937), $0.5 \mathrm{ml}$ of $2 \% \mathrm{FeCl}_{3}$ (freshly prepared) was mixed with $1 \mathrm{ml}$ of the culture supernatant and observed for the presence and absence of red color.

\section{Bioassay against fungal pathogen}

All the six strains were tested in vitro for their biocontrol activity against plant pathogenic fungi Cephalosporium maydis. C. maydis fungi was grown on a PDA plate till it covered the whole surface of the agar. A disc of fungal growth from this plate was taken by sterile cork borer and placed at the center of the fresh PDA plate. In triplicate, each bacterial strain was then streaked parallelly on either side of the fungal disc and kept for incubation at $28{ }^{\circ} \mathrm{C}$ for 7 days. The reduction in the growth of $C$. maydis was calculated, using the following formula: $\mathrm{RG}(\%)=C-T / C \times 100$, where $C$ is the growth of the test pathogen $(\mathrm{cm})$ in the absence of the antagonistic strain, and $T$ is the growth of the test pathogen $(\mathrm{cm})$ in the presence of the antagonistic strain.

\section{Pot experiment}

Soil from the experimental farm (Sakha Agric. Res. Station, Kafrelsheikh Gov.) was collected for the pot experiment. The soil was air-dried, passed through a ten mesh sieve, analyzed for physical and chemical properties Table 1, and then transferred to polyethylene bags filled with $4 \mathrm{~kg}$ of soil after being sterilized. In $0.5 \mathrm{~L}$ Erlenmeyer flasks, C. maydis fungi were inoculated into sterilized $250 \mathrm{ml}$ potato dextrose broth medium supplemented with $0.2 \%$ yeast extract, then incubated for 14 days at $28{ }^{\circ} \mathrm{C}$. After that, flasks were thoroughly shaken, and $20 \mathrm{ml}$ of the suspension was poured into $1 \mathrm{~L}$ Erlenmeyer flask, containing $2 / 3$ wet autoclaved grain sorghum and kept at $28{ }^{\circ} \mathrm{C}$ for 4 weeks. Soil infestation was carried out 1 week before planting by mixing $120 \mathrm{~g}$ of inoculum to the soil in every pot, followed by irrigation El-Shabrawy and Shehata (2018).

The grains of susceptible maize (Z. mays cv. Baladi) were surface sterilized with $70 \%$ ethanol and $5 \%$ sodium hypochlorite solution for 5-7 min, then washed five times with sterile distilled water. Each pot was seeded with four seeds and plants were thinned to two plants per pot. The 
Table 1 Some physicochemical properties of soil used in pot and field experiments

\begin{tabular}{llll}
\hline Soil properties & Pot experiment & \multicolumn{2}{c}{ Field experiment } \\
\cline { 3 - 4 } & & 2018 & 2019 \\
\hline Soil texture & Clayey & Clayey & Clayey \\
$\mathrm{pH}(1: 2.5$ water suspension) & 8.22 & 7.90 & 7.72 \\
$\mathrm{EC}\left(\mathrm{dS} \mathrm{m}{ }^{-1}\right)$ & 3.22 & 3.16 & 3.28 \\
Organic matter \% & 1.12 & 1.24 & 1.36 \\
Available P mg Kg & 8.24 & 9.33 & 10.03 \\
Available NH4 mg Kg & 9.70 & 12.60 & 15.66 \\
Available K mg Kg & 304 & 350 & 372 \\
Fe mg Kg & 2.54 & 2.62 & 2.67 \\
\hline
\end{tabular}

Physical and chemical analyses of soil used were determined by Department of Soil Chemistry, Soils, Water and Environment Research Institute, Agricultural Research Center

grains were inoculated with $1.0 \mathrm{~mL}$ of the grown cultures of tested bacterial strains, B. subtilis, B. circulance, B. coagulanse, B. licheniformis, $P$. fluroscence and $P$. koreensis, containing $3 \times 10^{9}$ cells $\mathrm{mL}^{-1}$. The cultures had been grown on Nutrient Broth medium on a rotary shaker for $48 \mathrm{~h}$ at $30^{\circ} \mathrm{C}$. Six pots were used for each strain, and sterile grains treated with non-inoculated culture media as well as other grains treated with fungicide (METAZED 38\% SC, $3 \mathrm{~cm} / 1 \mathrm{~kg}$ grains, Kafr El-Zayat pesticides and chemicals Co.) were used as control. At 21 days after planting, urea $(46 \% \mathrm{~N})$ as a nitrogen fertilizer was added at $300 \mathrm{mg} \mathrm{N} / \mathrm{kg}$ soil and the plants were irrigated regularly. The maize plants were harvested at 35-day age by mulching the plants from the pots. A replicate of three plants was used to measure pre- and post-emergence percentage (Nawar 2007). Also, vegetative growth such as fresh and dry weight $\left(\mathrm{g} \mathrm{plant}^{-1}\right)$, length of shoots and roots $(\mathrm{cm})$, as well as areal root, seminal root and stem diameter $(\mathrm{cm})$ were determined.

\section{Field trials}

Under field conditions, the impact of single and dual inoculation on the incidence of maize late wilt, vegetative growth and yield of susceptible maize plant (Baladi cv.) were studied in a disease nursery at Sakha Agriculture Research Station, Plant Pathology Research Institute, Agriculture Research Center, Kafrelsheikh Governorate, Egypt, during 2018 and 2019 growing seasons. This nursery was infested artificially with $C$. maydis (4 clonal lineages) that causes late wilt of maize and commonly used in Egyptian maize breeding programs (Zeller et al. 2002). The physical and chemical properties of soil used in this experiment are shown in Table 1. Plots were arranged in the field using a randomized complete block design. From the above-mentioned treatments in pot experiment, the most two tested bacterial strain treatments $B$. subtilis and P. koreensis were applied. The treatments were as follows: $\mathrm{T}_{1}$ : uninoculated (control), $\mathrm{T}_{2}$ : grains treated with fungicide (METAZED), $\mathrm{T}_{3}$ : inoculated with $B$. subtilis, $\mathrm{T}_{4}$ : inoculated with $P$. koreensis and $\mathrm{T}_{5}$ : inoculated with a mixture of $B$. subtilis and $P$. koreensis (1:1), with arrangement in three replicates. Fifteen milliliters of each culture $\left(1 \times 10^{8} \mathrm{CFU} \mathrm{ml}^{-1}\right)$ was mixed with $30 \mathrm{~g}$ of sterilized carrier, and then treated carefully with grains of maize using a sticking material before sowing. Each plot $(3 \times 4 \mathrm{~m})$ consisted of five ridges, $4 \mathrm{~m}$ in length and $60 \mathrm{~cm}$ apart, and the grains were sowed at the rate of 3 grains/hole with $20 \mathrm{~cm}$ space and the space between replications $1 \mathrm{~m}$. Thereafter, they were thinned to one plant/hole. According to the agricultural recommendations for maize by the Egyptian Ministry of Agriculture and Land Reclamation, irrigation and mineral fertilizers were applied.

\section{Measurements}

\section{Antioxidant enzymes and photosynthetic pigments}

At 60 days after sowing (DAS), three antioxidant enzyme activity catalase (Aebi (1984), peroxidase (Hammerschmidt et al. 1982), and polyphenol oxides (Malik and Singh 1980) were determined under this investigation. Also, total chlorophyll and carotenoids were determined according to Mousa et al. (2007).

\section{Disease incidence and stem histological differences}

Disease incidence and reduction $\%$ of late wilt were recorded at 85 DAS. Also, the histology of the stem of maize plants was measured according to the methods used by Abd ElGhani (1987). Briefly, from the second lower internodes, stem segments were taken and fixed for $36 \mathrm{~h}$ in a mixture of acetic acid, formalin, ethyl alcohol $70 \%$ and water at the rate of 5, 10, 50 and $35 \mathrm{ml}$, respectively, then transferred to ethanol $70 \%$ until use. The drying process was performed with an increase in the concentrations of ethanol and $N$-butanol series, then embedded into paraffin wax $\left(58^{\circ} \mathrm{C}\right)$. By a rotary microtome, cross sections were cut ( $15 \mu \mathrm{m}$ thickness) and fixed on microscopic slides with Haupt's adhesive ( $1 \mathrm{~g}$ gelatin $+2 \mathrm{~g}$ phenol $+15 \mathrm{ml}$ glycerol $+100 \mathrm{ml}$ water $)$, as mentioned by Sass (1961). Slides were left to completely dry in the oven at $40^{\circ} \mathrm{C}$ for 1 day. Sections were stained with $1 \%$ safranin and $1 \%$ light green dyes, cleared in xylene, mounted in Canada balsam and examined microscopically.

\section{Yield and yield component}

During the harvest period, quantitative and qualitative maize yield such as ear length $(\mathrm{cm})$, ear diameter $(\mathrm{cm})$, number of 
rows per ear, 100-grains weight $(\mathrm{g})$ and yield (ton ha ${ }^{-1}$ ) were evaluated during the 2018 and 2019 seasons.

\section{Statistical analysis}

Statistical analysis of data was conducted, using SPSS 14.0 for windows and the mean values were compared by Duncan's multiple range test at $P \leq 0.05$ (Duncan 1955).

\section{Results}

\section{Qualitative and quantitative assays for siderophore production}

In the present investigation, six strains of $B$. subtilis, $B$. circulance, B. coagulanse, B. licheniformis, $P$. fluroscence and $P$. koreensis were screened by five different siderophore assays, viz., CAS-agar assay, CAS-liquid assay, Arnow's assay, Csáky test and $\mathrm{FeCl}_{3}$ test (Table 2; Fig. 1).

All tested strains exhibited an orange halo after 5 days of incubation at $30{ }^{\circ} \mathrm{C}$ on CAS agar plate and, therefore, were considered positive for siderophore production. Among the strains, intensity of orange halo and diameter showed wide variation which ranged from $1.62 \mathrm{~cm}(B$. subtilis) to $0.36 \mathrm{~cm}$ (B. licheniformis). So, B. subtilis and $P$. koreensis strains were identified as producer of more avid iron chelator. On the other hand, two strains of $B$. subtilis and $B$. coagulanse showed siderophore positive in Arnow's assay. On the contrary, three strains of $B$. licheniformis, $P$. fluroscence and $P$. koreensis showed siderophore positive in Csáky test. $\mathrm{FeCl}_{3}$ test was siderophore positive for B. subtilis and B. coagulanse strains as compared to other tested strains.

Using the dual culture technique, six bacterial strains were tested for antagonistic activity against $C$. maydis (Fig. 2 and Supplementary Figure 1). After 7-day cultivation on PDA medium, all strain treatments inhibited the growth of $C$. maydis in dual culture compared to the control. The antifungal activity of $B$. subtilis and P. koreensis strains reduced the growth of $C$. maydis by 4.36 and $4.26 \mathrm{~cm}$ (Fig. 2a), and the reduction \% attained was 51.55 and 52.66 (Fig. 2b), respectively, compared to other tested strains. In addition, antifungal activity of $B$. licheniformis strain was
Table 2 Quantitative and qualitative assays of siderophore produced by different bacterial strains

\begin{tabular}{lllllc}
\hline Stains & CAS-agar $\left(\mathrm{cm}^{-1}\right)$ & CAS-liquid (\%) & $\begin{array}{l}\text { Arnow's } \\
\text { assays }\end{array}$ & Csáky test & $\mathrm{FeCl}_{3}$ test \\
\hline B. subtilis & $1.62 \pm 0.06$ & $18.14 \pm 0.64$ & + & - & + \\
B. circulance & $0.92 \pm 0.04$ & $9.02 \pm 0.14$ & - & - & - \\
B. coagulanse & $0.72 \pm 0.03$ & $8.10 \pm 0.30$ & + & - & + \\
B. licheniformis & $0.36 \pm 0.03$ & $7.22 \pm 0.14$ & - & + & - \\
P. fluroscence & $1.09 \pm 0.07$ & $11.50 \pm 0.19$ & - & + & - \\
P. koreensis & $1.50 \pm 0.02$ & $16.03 \pm 0.18$ & - & + & - \\
\hline
\end{tabular}

Values are average of three replications; values after \pm represent standard deviation. Antagonistic activity tests

+ siderophore positive, - siderophore negative
A

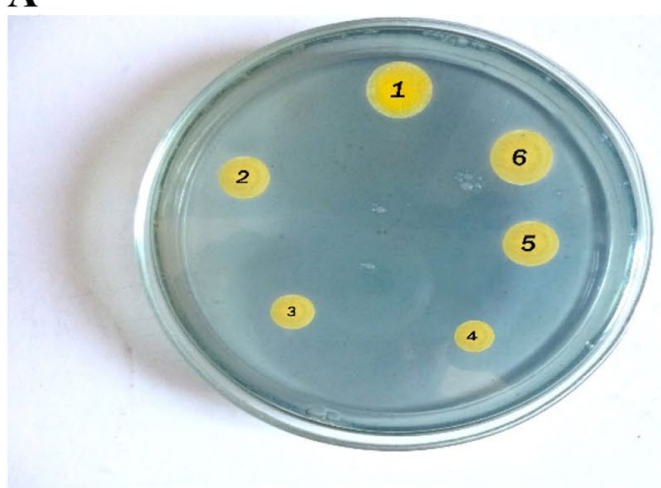

B

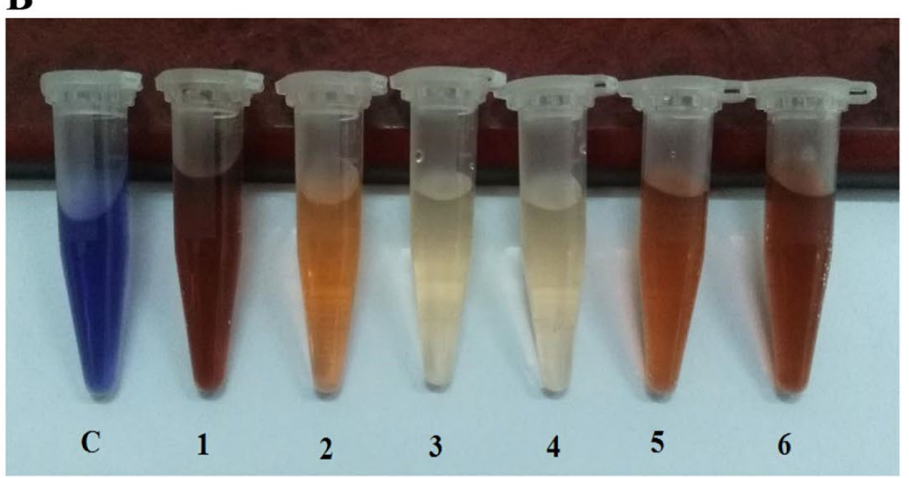

Fig. 1 Comparison of siderophore production in different bacterial strains, a siderophore production in the six strains was detected on CAS agar plates, $\mathbf{b}$ siderophore production in the six strains was detected in CAS liquid, C: control; 1: B. subtilis, 2: B. circulance, 3: B. coagulanse, 4: B. licheniformis, 5: P. fluroscence and 6: P. koreensis 


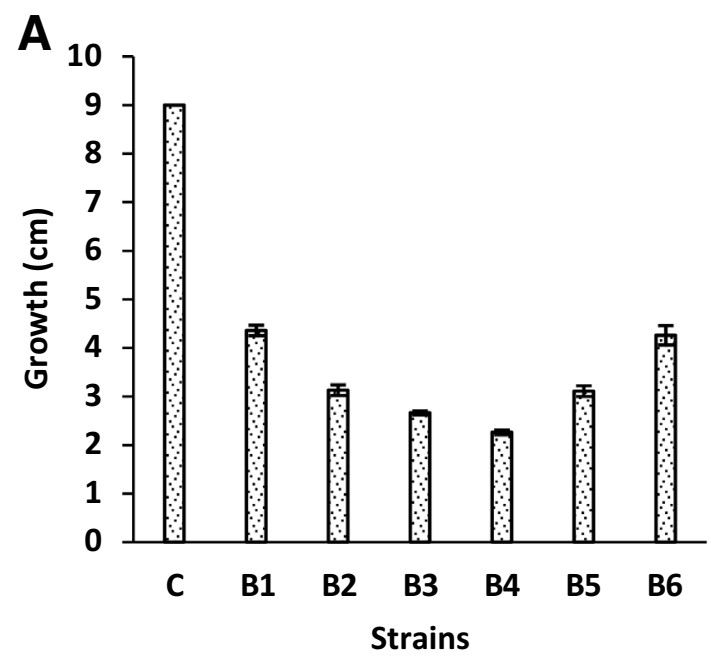

Fig. 2 Mycelial growth inhibition of $C$. maydis by tested bacterial strains in dual culture test on PDA after 7 days of incubation at $28{ }^{\circ} \mathrm{C}$ : a linear growth; b reduction \%; c control; B1: B. subtilis, B2: B. cir-

less than that of other strains and recorded $2.26 \mathrm{~cm}$ growth and $74.44 \%$ reduction.

\section{Pot experiment}

\section{Antagonistic effect and growth promotion studies}

The effects of antagonistic bacterial strains (B. subtilis, $B$. circulance, $B$. coagulanse, $B$. licheniformis, $P$. fluroscence and $P$. koreensis) on the pre- and post-emergence damping off of $C$. maydis and growth promotion studies of maize plants in greenhouse are shown in Fig. 3 and Table 3.
B

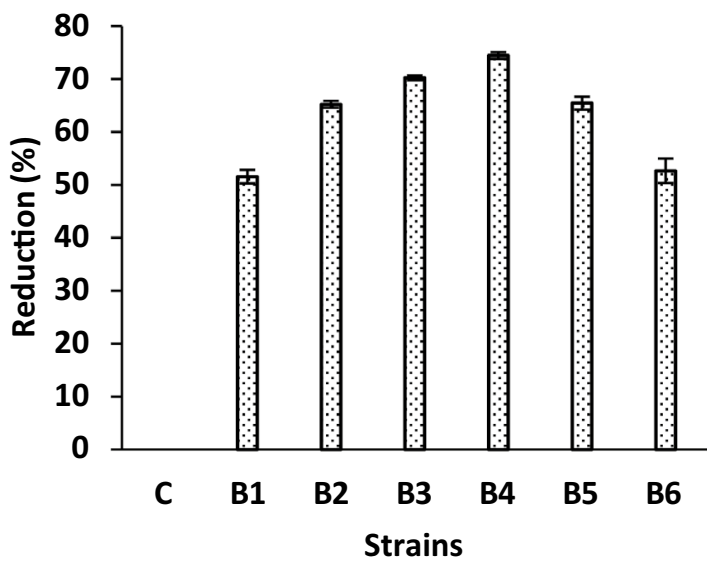

culance, B3: B. coagulanse, B4: B. licheniformis, B5: P. fluroscence and B6: P. koreensis. Values are average of three replications and the results are shown as mean $\pm \mathrm{SD}$

Data of Fig. 3 showed that all inoculation treatments decreased damping off $\%$ and increased healthy plants compared with the control treatments (T1 and T2). The lowest pre-emergence damping-off plants ( 15 days) were recorded for the treatments T3 and T8 (11.66\%) compared to other treatments. Also, the post-emergence percentages of damping-off plants (30 days) showed notable decreases due to the different studied bacterial strains; therefore, the most effective treatments were $\mathrm{T} 3, \mathrm{~T} 7$ and $\mathrm{T} 8$ which completely prevent post-emergence. Concerning the growth promotion parameters (Table 3), T3 treatment (grains inoculated with $B$. subtilis) attained an increase rate of $37.42 \%$ in fresh weight, $84.79 \%$ in dry weight, $76.29 \%$ in root length, $21.47 \%$

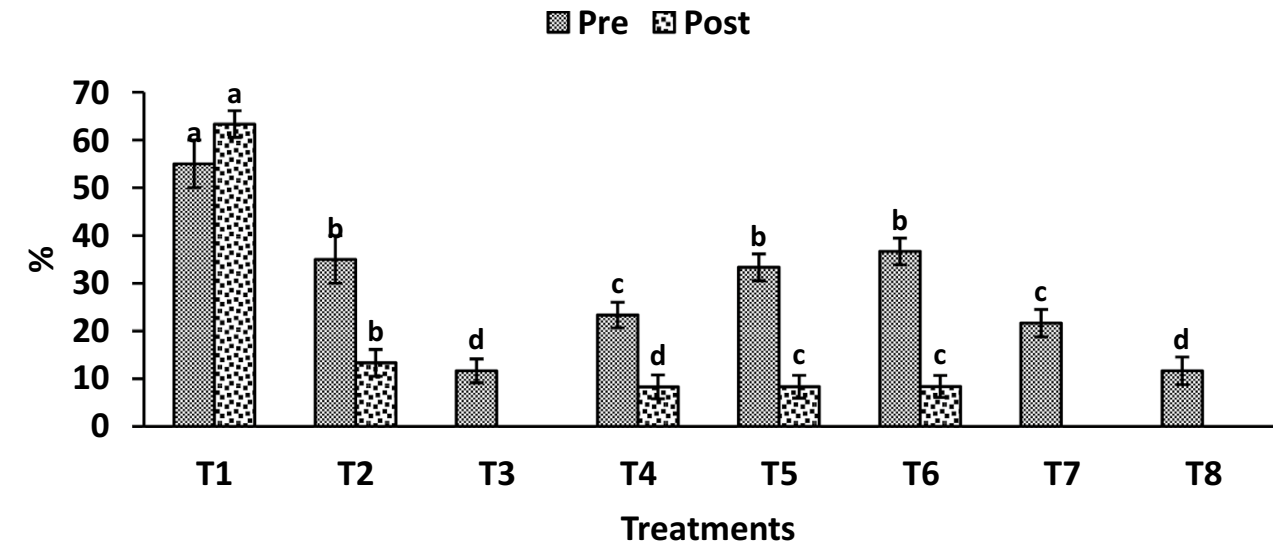

Fig. 3 Effect of antagonistic bacterial strains on the pre- and postemergence damping off of $\mathrm{C}$. maydis under greenhouse conditions. T1: uninoculated (control); T2: grains treated with fungicide; T3: grains inoculated with $B$. subtilis; T4: grains inoculated with $B$. cir- culance; T5: grains inoculated with $B$. coagulanse; T6: grains inoculated with $B$. licheniformis; T7: grains inoculated with P. fluroscence; T8: grains inoculated with $P$. koreensis. Values are average of three replications and the results are shown as mean $\pm \mathrm{SD}$ 
Table 3 Effect of antagonistic bacterial strains on growth promotion studies of maize plant in soil infested with $C$. maydis under greenhouse conditions

\begin{tabular}{|c|c|c|c|c|c|c|c|}
\hline Treatments & $\begin{array}{l}\text { Fresh weight (g } \\
\text { plant }^{-1} \text { ) }\end{array}$ & $\begin{array}{l}\text { Dry weight (g } \\
\text { plant }^{-1} \text { ) }\end{array}$ & Root length $(\mathrm{cm})$ & Shoot length $(\mathrm{cm})$ & Areal root & Seminal root & Stem diameter $(\mathrm{cm})$ \\
\hline $\mathrm{T} 1$ & $62.33 \pm 2.08^{\mathrm{e}}$ & $19.66 \pm 2.08^{\mathrm{f}}$ & $19.66 \pm 2.08^{\mathrm{f}}$ & $63.66 \pm 1.52^{\mathrm{e}}$ & $4.33 \pm 0.57^{\mathrm{c}}$ & $13.00 \pm 1.00^{\mathrm{e}}$ & $4.60 \pm 0.10^{\mathrm{de}}$ \\
\hline $\mathrm{T} 2$ & $65.66 \pm 2.08^{\mathrm{d}}$ & $22.66 \pm 1.52^{\mathrm{e}}$ & $24.00 \pm 1.00^{\mathrm{e}}$ & $66.33 \pm 1.52^{\mathrm{d}}$ & $4.33 \pm 0.57^{\mathrm{c}}$ & $14.33 \pm 0.57^{\text {cde }}$ & $4.73 \pm 0.11^{\mathrm{cd}}$ \\
\hline $\mathrm{T} 3$ & $85.66 \pm 2.08^{\mathrm{a}}$ & $36.33 \pm 2.08^{\mathrm{a}}$ & $34.66 \pm 2.08^{\mathrm{a}}$ & $77.33 \pm 1.52^{\mathrm{a}}$ & $6.66 \pm 0.57^{\mathrm{a}}$ & $19.00 \pm 1.00^{\mathrm{a}}$ & $5.53 \pm 0.15^{\mathrm{a}}$ \\
\hline $\mathrm{T} 4$ & $75.66 \pm 1.52^{b}$ & $29.00 \pm 1.00^{c}$ & $29.00 \pm 1.00^{\mathrm{bc}}$ & $74.33 \pm 0.57^{\mathrm{b}}$ & $5.66 \pm 0.57^{\mathrm{ab}}$ & $15.00 \pm 1.00^{\mathrm{bcd}}$ & $5.13 \pm 0.05^{\mathrm{b}}$ \\
\hline $\mathrm{T} 5$ & $70.66 \pm 2.08^{c}$ & $25.00 \pm 1.00^{\mathrm{de}}$ & $26.66 \pm 1.52^{\mathrm{cd}}$ & $67.33 \pm 1.52^{\mathrm{d}}$ & $4.33 \pm 0.57^{\mathrm{c}}$ & $13.66 \pm 0.57^{\mathrm{de}}$ & $4.80 \pm 0.10^{\mathrm{c}}$ \\
\hline T6 & $65.33 \pm 2.08^{\mathrm{e}}$ & $23.00 \pm 1.00^{\mathrm{e}}$ & $25.00 \pm 1.00^{\mathrm{de}}$ & $62.00 \pm 1.00^{\mathrm{e}}$ & $4.33 \pm 0.57^{\mathrm{c}}$ & $13.00 \pm 1.00^{\mathrm{e}}$ & $4.50 \pm 0.10^{\mathrm{e}}$ \\
\hline $\mathrm{T} 7$ & $75.66 \pm 0.57^{\mathrm{b}}$ & $27.33 \pm 1.15^{\mathrm{cd}}$ & $30.00 \pm 1.00^{\mathrm{b}}$ & $70.00 \pm 1.00^{\mathrm{c}}$ & $5.00 \pm 1.00^{\mathrm{c}}$ & $15.33 \pm 0.57^{\mathrm{bc}}$ & $5.06 \pm 0.11^{\mathrm{b}}$ \\
\hline $\mathrm{T} 8$ & $83.66 \pm 1.52^{\mathrm{a}}$ & $32.33 \pm 2.08^{\mathrm{b}}$ & $33.33 \pm 0.57^{\mathrm{a}}$ & $74.00 \pm 1.00^{\mathrm{b}}$ & $6.66 \pm 0.57^{\mathrm{a}}$ & $16.33 \pm 0.57^{b}$ & $5.40 \pm 0.10^{\mathrm{a}}$ \\
\hline
\end{tabular}

Values are average of three replications and the results are shown as mean $\pm \mathrm{SD}$; the letters show significance at $P \leq 0.05$

$T 1$ uninoculated (control), T2 grains treated with fungicide, T3 grains inoculated with B. subtilis, T4 grains inoculated with B. circulance, T5 grains inoculated with $B$. coagulanse, T6 grains inoculated with B. licheniformis, $T 7$ grains inoculated with $P$. fluroscence, $T 8$ grains inoculated with P. koreensis

in shoot length, $53.81 \%$ in areal root, $46.15 \%$ in seminal root and $20.21 \%$ in stem diameter compared to control treatments (T1). Of the six studied antagonists, B. subtilis and P. koreensis were observed to perform better in antagonistic effect and growth promotion parameters.

\section{Field experiment}

\section{Antioxidant enzymes, total chlorophyll and carotenoids}

The presented results in Fig. 4, show that the antioxidant enzymes' activity (CAT, POX and PPO), as well as total chlorophyll and carotenoids significantly improved in plants exposed to inoculation treatments under soil infested conditions with $C$. maydis at 60 days during the two growing seasons.

The highest values of CAT activity $\left(\mathrm{mM} \mathrm{H}_{2} \mathrm{O}_{2} \mathrm{~g}^{-1} \mathrm{FW} \mathrm{min}{ }^{-1}\right)$ in treated plants were determined to be increased from 9.00 (control) to 12.66 (grains treated with fungicide), 18.66 (inoculated with B. subtilis), 22.33 (inoculated with $P$. koreensis) and 27.00 (inoculated with a mixture of B. subtilis and P. koreensis) in the season 2018, whereas in the season 2019 the same treatments increased CAT activity from 11.33 (control) to 14.00 (grains treated with fungicide), 19.66 (inoculated with $B$. subtilis), 23.66 (inoculated with $P$. koreensis) and 28.66 (inoculated with a mixture of $B$. subtilis and $P$. koreensis) significantly as shown in Fig. 4.

Additionally, soil infested with $C$. maydis caused a reduction in POX activity as found in untreated maize plants, while treating plants with bioinoculation alleviated the detrimental effect of soil infested with $C$. maydis on antioxidant capacity represented in POX activity. Among all treatments, T5 (inoculated with a mixture of B. subtilis and $P$. koreensis) induced the activity of POX enzyme $\left(\mathrm{mM} \mathrm{H} \mathrm{H}_{2} \mathrm{O}^{-1} \mathrm{FW} \mathrm{min}^{-1}\right.$ ) recording higher values than control, which changed significantly from 107.33 (control) to 172.66 (T5) in the season 2018. Likewise, in the season 2019, POX activity recorded 115.66 (control) to 180.00 (T5) (Fig. 4). In the same way, the highest values of PPO enzyme activity ( $\mu \mathrm{M}$ tetra-guaiacol $\mathrm{g}^{-1} \mathrm{FW} \mathrm{min}^{-1}$ ) recorded 0.28 and 0.32 for T5 treatment, followed by 0.22 and 0.26 for $\mathrm{T} 3$ treatment and 0.18 and 0.22 for T4 treatment during the 2018 and 2019 seasons, respectively, compared to control treatment (Fig. 4).

Our findings for total chlorophyll and carotenoids was statistically significant $(P \leq 0.05)$. Data showed that an increase in total chlorophyll and carotenoids was observed with T5 treatment (inoculated with a mixture of $B$. subtilis and $P$. koreensis) resulted in 2.28 and $0.79 \mathrm{mg} \mathrm{g}^{-1} \mathrm{FW}$, followed by 2.07 and $0.68 \mathrm{mg} \mathrm{g}^{-1} \mathrm{FW}$ for T4 treatment (inoculated with $P$. koreensis) and 1.88 and $0.63 \mathrm{mg} \mathrm{g}^{-1}$ FW for T3 treatment (inoculated with B. subtilis) compared to control in the season 2018, respectively. A similar trend was observed in the season 2019 (Fig. 4).

\section{Efficiency of treatments on maize late wilt disease and stem histological differences}

Under artificial soil infestation, data presented in Figs. 5 and 6 showed that grains treated with bacterial inoculation either alone or in combination significantly reduced the infection percentage with late wilt disease and increase in reduction percentage compared to the control treatment. For disease incidence, treatment with a mixture of B. subtilis and $P$. koreensis (T5) gave the highest effect in reducing infection 13.33 and $14.66 \%$, followed by treatment with B. subtilis (T3) 23.00 and $20.55 \%$ compared to control treatment (T1) 
Fig. 4 Effect of inoculation with $B$. subtilis and P. koreensis alone or in combination on activities of catalase (CAT), peroxidase (POX), polyphenol oxidase (PPO), total chlorophyll and carotenoids of maize plants at 60 days in the 2018 and 2019 seasons. T1: uninoculated (control), T2: grains treated with fungicide, T3: inoculated with $B$. subtilis, T4: inoculated with $P$. koreensis and T5:

inoculated with a mixture of $B$. subtilis and $P$. koreensis. Values are average of three replications and the results are shown as mean \pm standard errors and the letters show significance at $P \leq 0.05$

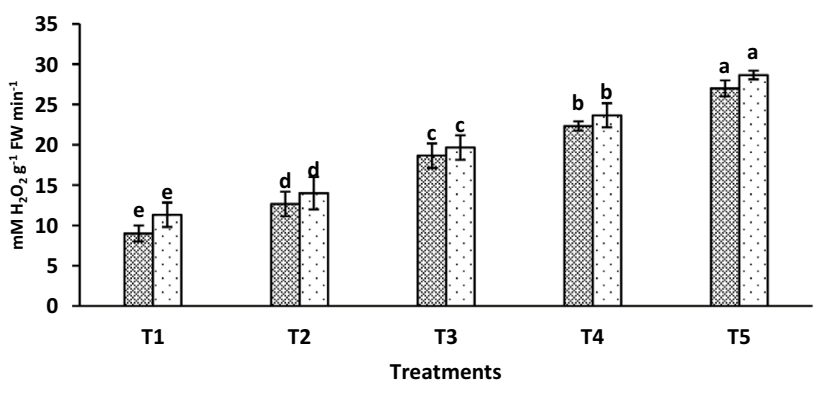

POX

응 $2018 \square 2019$

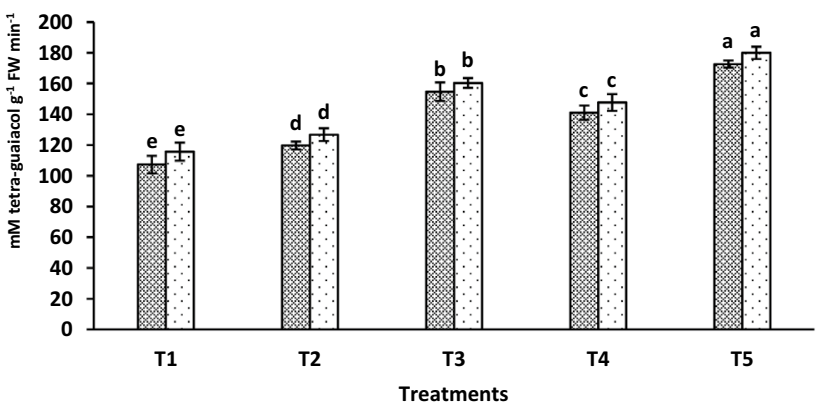

PPO

冈2018 ๑2019

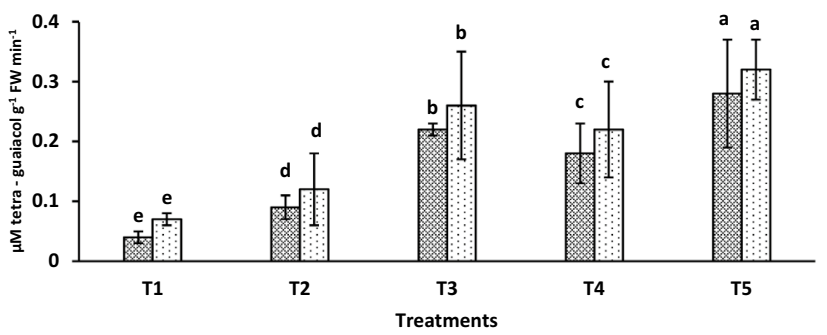

Total Chlorophyll

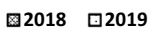

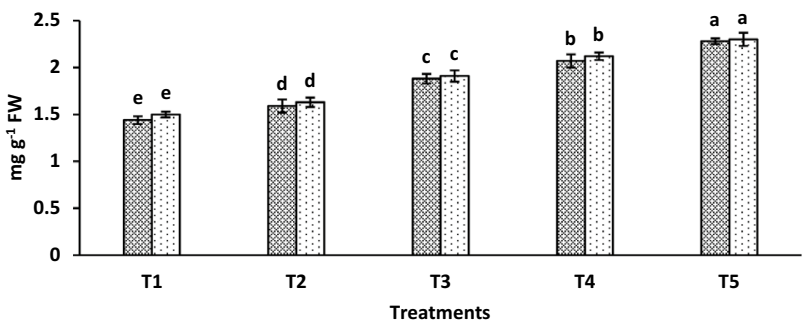

Carotenoids

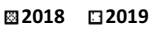

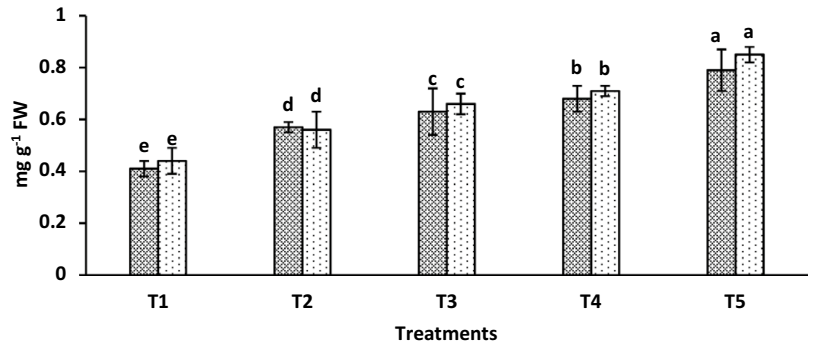




\section{Disease incidence \% $\quad \mathbf{R}$ Reduction \%}

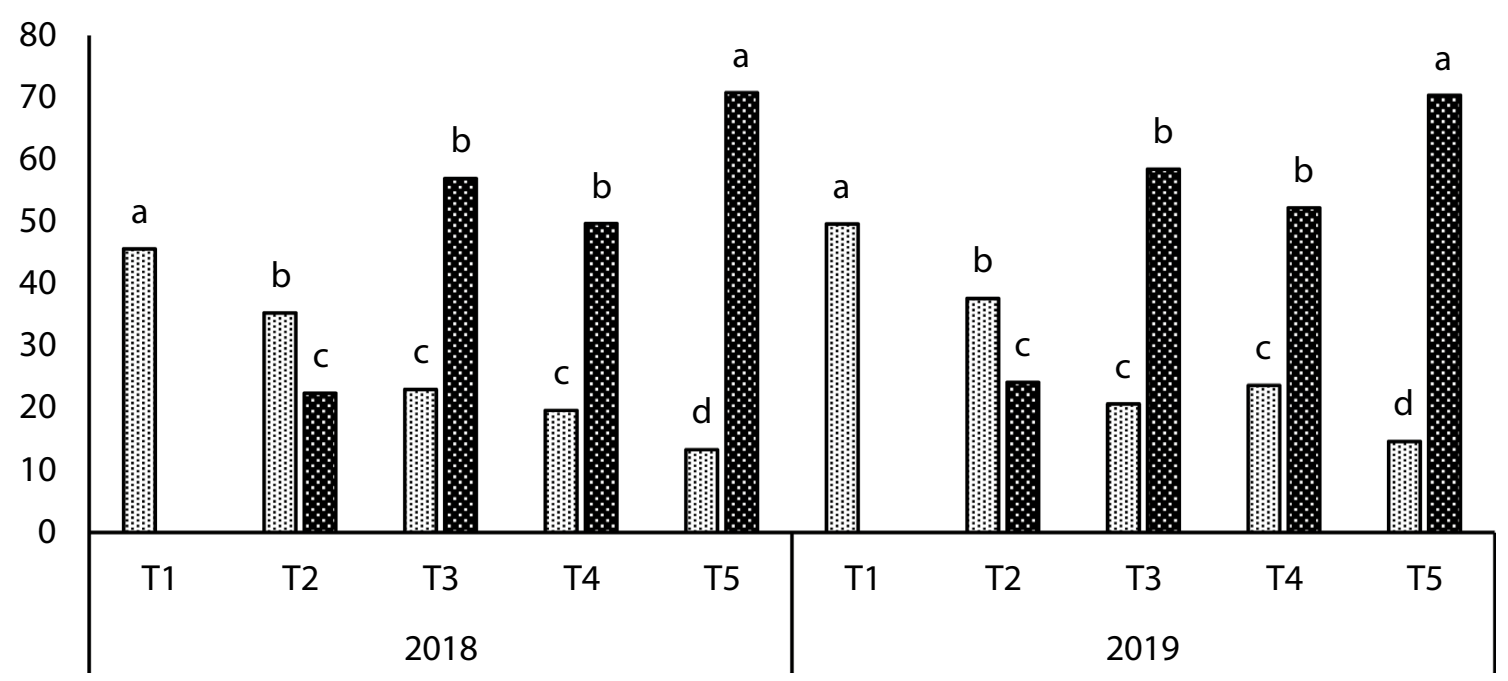

Fig. 5 Effect of inoculation with B. subtilis and P. koreensis alone or in combination on the incidence of late wilt of maize grown under field conditions during 2018 and 2019 seasons, T1: uninoculated (control), T2: grains treated with fungicide, T3: inoculated with $B$.

45.66 and $49.66 \%$ during the 2018 and 2019 seasons, respectively. Similar trend was observed in reduction \% in the season 2018 and 2019 with the studied treatments following the descending order of $\mathrm{T} 5>\mathrm{T} 3>\mathrm{T} 4>\mathrm{T} 2>\mathrm{T} 1$ (Fig. 5).

On the other hand, the cross section of maize plant stem at 85 days after sowing, in Fig. 6, showed increase in the thickness of the sclerenchymatous sheath layer surrounding the vascular bundles in bacterial inoculation treatments (T3, T4 and T5) compared to uninoculated treatments (T1 and T2). Also, it is worth to note the presence of C. maydis aggregates in the xylem vessels of control treatments (Fig. 6a, b), whereas these did not appear in the xylem vessels of inoculation treatments (Fig. 6c-e).

\section{Yield and yield components}

A perusal of results (Table 4) revealed that inoculation treatments either alone or in combination showed significant influence for yield and yield-related parameters (ear length, ear diameter, number of rows/ears and 100 grain weight) on soil infested with $C$. maydis, whereas uninoculated treatments had no significant effect.

The combination treatment (T5) caused the maximum values of ear length $(\mathrm{cm})$, ear diameter $(\mathrm{cm})$ and number of row/ear recorded as $23.00,4.58$ and 13.46 , respectively, compared to the control (T1), recorded as $20.43,4.16$ and 10.73 in the season 2018. Likewise, in season 2019, T5 treatment recorded 23.20, 4.61 and 13.66 compared to T1 treatment (control) that recorded 20.66, 4.25 and 10.80 for ear length $(\mathrm{cm})$, ear diameter $(\mathrm{cm})$ and number of rows/ears, subtilis, T4: inoculated with P. koreensis and T5: inoculated with a mixture of $B$. subtilis and $P$. koreensis. Values are average of three replications and the letters show significance at $P \leq 0.05$

respectively (Table 4). In regard to 100 grain weight, a different increase rate was noticed between single and dual inoculation treatments compared to control, where 21.38 and $21.08 \%$ at T5 treatment (inoculated with a mixture of B. subtilis and P. koreensis), 4.11 and $3.86 \%$ at T4 treatment ((inoculated with P. koreensis), and 7.67 and $7.46 \%$ at $\mathrm{T} 3$ treatment ((inoculated with B. subtilis) were recorded during the 2018 and 2019 seasons, respectively (Table 4).

On the other hand, the positive effect caused by dual inoculation treatment on the yield of maize plants which was 10.04 and 10.12 ton $\mathrm{ha}^{-1}$ recorded an increase rate of 60.24 and $51.27 \%$ during the 2018 and 2019 seasons, respectively, compared to the control treatment (Table 4).

\section{Discussion}

It is important to understand the mechanisms involved in the interactions between microorganisms, pathogens, and host plants for the better use of natural resources in crop productivity management (Thomashow and Weller 1991). One of these mechanism are siderophores production, which are defined as low molecular weight organic compounds $(<10 \mathrm{kDa})$ that are excreted by microorganisms living in low iron conditions (Oswald 2010), and is one of the mechanisms of antagonism and biocontrol agents (Sinha and Parli 2020) that has been proved in plant growth-promoting bacteria (Yang et al. 2011). In the present study, a total of six PGPR strains were tested in laboratory to produce siderophores using CAS-agar assay, CAS-liquid assay, Arnow's 

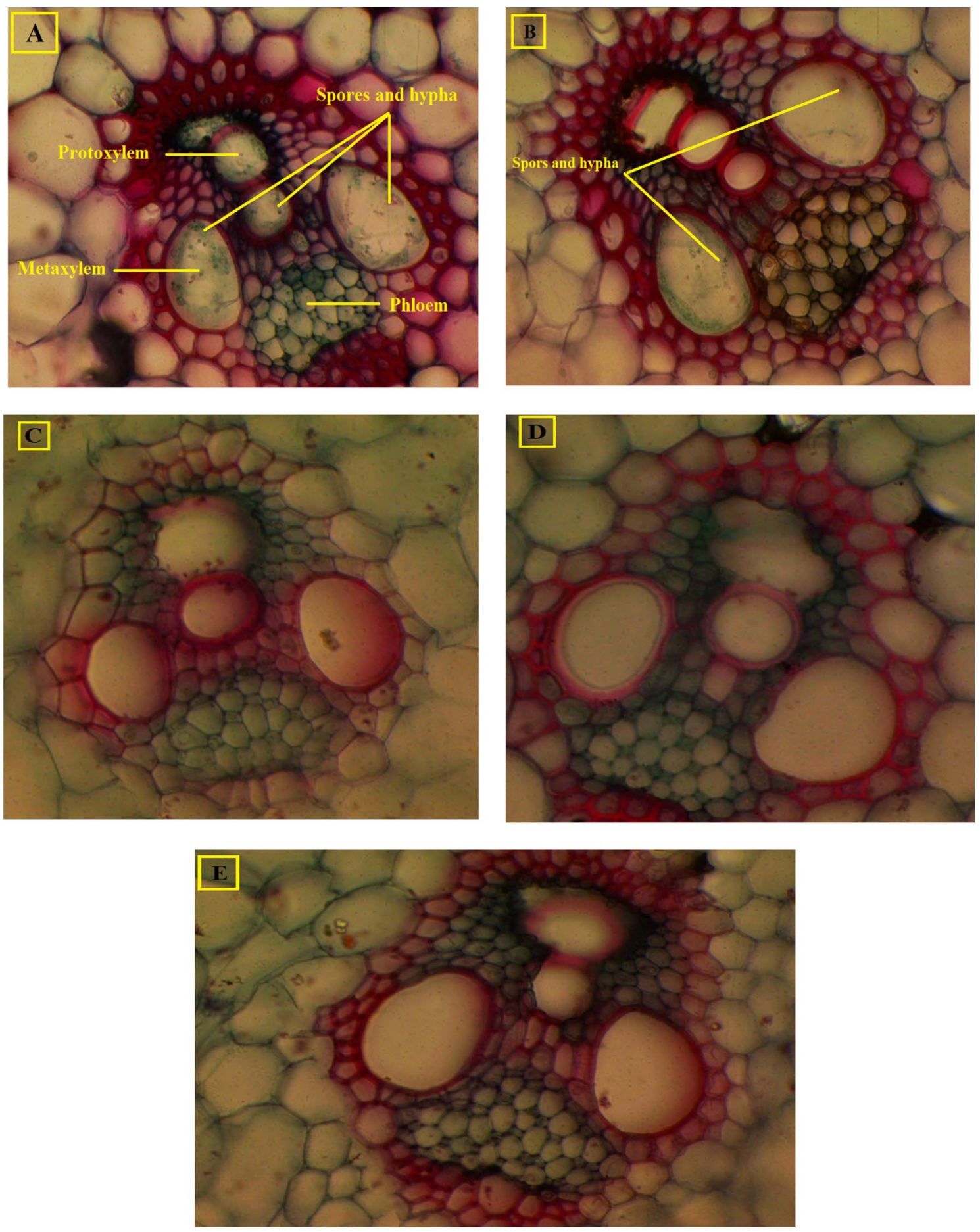

Fig. 6 Transverse section (X 400) in the second stem internode of maize plants at 85 days from sowing during 2019 season; a control (T1), b grains treated with fungicide (T2), c inoculated with $B$. subti-

assay, Csáky test and $\mathrm{FeCl}_{3}$ test. Two strains, $B$. subtilis and $P$. koreensis, were found to be the most qualitative and quantitative assays for siderophore production (Table 2; Fig. 1). Rajkumar et al. (2010) showed that bacterial cells produce many types of siderophores, i.e., hydroxamate, catecholate, lis (T3), d inoculated with $P$. koreensis (T4), and e inoculated with a mixture of B. subtilis and P. koreensis (T5)

salicylate and carboxylate. These siderophores play a vital role in the accumulation of $\mathrm{Fe}$ from various organic materials (Balagurunathan and Radhakrishnan 2007).

The antagonistic activity tested in our study effectively suppressed the mycelial growth of $C$. maydis in in vitro 
Table 4 Effect of inoculation with $B$. subtilis and P. koreensis alone or in combination on some parameters of yield and yield component of maize plants grown under field conditions during 2018 and 2019 seasons

\begin{tabular}{llllll}
\hline Treatment & Ear length $(\mathrm{cm})$ & Ear diameter $(\mathrm{cm})$ & No. of row/ear & 100 grain weight $(\mathrm{g})$ & $\begin{array}{l}\text { Yield } \\
\left(\text { ton } \mathrm{ha}^{-1}\right)\end{array}$ \\
\hline 2018 & & & & \\
T1 & $20.43 \pm 0.3 \mathrm{e}$ & $4.16 \pm 0.15 \mathrm{c}$ & $10.73 \pm 0.2 \mathrm{e}$ & $30.11 \pm 0.09 \mathrm{e}$ & $6.64 \pm 0.07 \mathrm{e}$ \\
T2 & $21.26 \pm 0.3 \mathrm{~d}$ & $4.40 \pm 0.1 \mathrm{bc}$ & $11.26 \pm 0.25 \mathrm{~d}$ & $30.51 \pm 0.14 \mathrm{~d}$ & $7.29 \pm 0.1 \mathrm{~d}$ \\
T3 & $21.86 \pm 0.05 \mathrm{c}$ & $4.33 \pm 0.15 \mathrm{ab}$ & $12.16 \pm 0.15 \mathrm{c}$ & $32.42 \pm 0.1 \mathrm{c}$ & $8.41 \pm 0.1 \mathrm{c}$ \\
T4 & $22.36 \pm 0.15 \mathrm{~b}$ & $4.50 \pm 0.1 \mathrm{ab}$ & $12.80 \pm 0.1 \mathrm{~b}$ & $31.35 \pm 0.18 \mathrm{~b}$ & $9.52 \pm 0.09 \mathrm{~b}$ \\
T5 & $23.00 \pm 0.2 \mathrm{a}$ & $4.58 \pm 0.7 \mathrm{a}$ & $13.46 \pm 0.37 \mathrm{a}$ & $36.55 \pm 0.22 \mathrm{a}$ & $10.04 \pm 0.02 \mathrm{a}$ \\
LSD 0.05 & 0.442 & 0.215 & 0.467 & 0.237 & 0.106 \\
2019 & & & & & \\
T1 & $20.66 \pm 0.2 \mathrm{~d}$ & $4.25 \pm 0.13 \mathrm{c}$ & $10.80 \pm 0.1 \mathrm{e}$ & $30.26 \pm 0.08 \mathrm{e}$ & $6.69 \pm 0.03 \mathrm{e}$ \\
T2 & $21.63 \pm 0.05 \mathrm{c}$ & $4.41 \pm 0.09 \mathrm{bc}$ & $11.36 \pm 0.25 \mathrm{~d}$ & $30.74 \pm 0.02 \mathrm{~d}$ & $7.31 \pm 0.15 \mathrm{~d}$ \\
T3 & $22.56 \pm 0.57 \mathrm{~b}$ & $4.37 \pm 0.13 \mathrm{bc}$ & $12.30 \pm 0.1 \mathrm{c}$ & $32.52 \pm 0.03 \mathrm{c}$ & $8.49 \pm 0.07 \mathrm{c}$ \\
T4 & $22.60 \pm 0.1 \mathrm{~b}$ & $4.54 \pm 0.08 \mathrm{ab}$ & $12.86 \pm 0.05 \mathrm{~b}$ & $31.43 \pm 0.03 \mathrm{~b}$ & $9.54 \pm 0.08 \mathrm{~b}$ \\
T5 & $23.20 \pm 0.26 \mathrm{a}$ & $4.61 \pm 0.03 \mathrm{a}$ & $13.66 \pm 0.2 \mathrm{a}$ & $36.64 \pm 0.02 \mathrm{a}$ & $10.12 \pm 0.02 \mathrm{a}$ \\
LSD 0.05 & 0.529 & 0.180 & 0.328 & 0.080 & 0.103 \\
\hline
\end{tabular}

T1: uninoculated (control), T2: grains treated with fungicide, T3: inoculated with B. subtilis, T4: inoculated with $P$. koreensis and T5: inoculated with a mixture of B. subtilis and P. koreensis. Values are average of three replications and the results are shown as mean \pm standard errors. The presented data are the mean \pm standard errors, and the letters show significance at $\mathrm{P} \leq 0.05$ assays (Fig. 2). Data indicated that B. subtilis and P. koreensis proved to be the most effective antagonist than other tested strains which reduced the growth of $C$. maydis by 4.36 and $4.26 \mathrm{~cm}$ (Fig. 2a), and the reduction \% attained was 51.55 and 52.66 (Fig. 2b), respectively. The suppression of mycelial growth of $C$. maydis was mainly due to the diffusible antifungal substances such as hydrolytic enzymes, antibiotics or some other secondary metabolites (Beneduzi et al. 2012). The antagonistic activities of Bacillus and Pseudomonas were recognized by many researchers. Ferreira et al. (1991) showed that different Bacillus spp. can produce 66 types of antibiotic compounds against bacteria and fungi such as bacillomycin, fengycin, mycosubtilin, and zwittermicin, which are effective in suppressing the growth of target pathogens in vitro (Kim et al. 2008). Also, many biocontrol agents of Pseudomonas spp. can produce extracellular secondary metabolities such as cepacins, testin, 2,4-diacetylphloroglucinol, pyoluteorin, phenazine, pyrrolnitrin, pyoverdine and altericidines that inhibit the growth of some soilborne fungal pathogens (Mavrodi et al. 2001; Subagio and Foster 2003), and are attributed to the production of siderophores, volatile compounds, cell wall-degrading molecules, extracellular chitinase, and protease enzymes activity (Mavrodi et al. 2001). Likewise, under in vitro conditions, Sandani et al. (2019) showed that Burkholderia and Pseudomonas bacteria are effective antagonists of $C$. truncatum causing anthracnose. Also, Ali et al. (2018) studied 40 PGPR strains which are able to produce siderophores as well as have a significant growth suppression of pathogenic $F$. oxysporum and $R$. solani. El-Shabrawy and Shehata (2018) demonstrated that maize grain treated with $B$. subtilis and
P. fluorescens had a significant reduction in late wilt disease under greenhouse conditions.

Influence of the tested bacterial strains on the disease expressions of maize plants grown in soil infested with $C$. maydis under greenhouse conditions are studied by pre- and post-emergence damping off in this study Fig. 3. Results showed that the most effective treatments were T3 (grains inoculated with $B$. subtilis), T7 (grains inoculated with $P$. fluroscence) and T8 (grains inoculated with P. koreensis) which completely prevent pre- and post-emergence. These results may be due to the effective antibiotics (PCA, PLT, DAPG and PLN) and lipase, pectinase, amylase and protease enzymes as well as siderophores (pyoverdine and pyochelin) that are produced by $P$. fluorescens, which showed antagonistic activity toward C. maydis (Ebrahim 2010). Also, Bacillus spp. have modes of action such as antibiosis, parasitism, colonization, competition and induced systemic resistance (Jacobsen et al. 2004). Similar findings against C. maydis by actinomycetes and yeast fungi were stated by El-Mehalawy et al. (2004). Hamza et al. (2013) reported that the formulations of B. subtilis, B. pumilus, P. fluorescens and Epicoccum nigrum caused noticeable reduction in maize late wilt. Also, El-Shabrawy and Shehata (2018) found that significant reduction in the disease incidence was recorded by maize grains treated with $P$. fluorescens, either individually or in combination with $B$. subtilis. Concerning the growth promotion parameters, results showed that grains inoculated with $B$. subtilis (T3) and grains inoculated with $P$. koreensis (T8) attained significant increase in fresh weight, dry weight, root length, shoot length, areal root, seminal root and stem diameter compared to control treatments in soil infested with 
C. maydis under greenhouse conditions (Table 3). These results reflect the role of the tested bioagent inoculants in their effects on growth parameters and control plants such as stimulating cell division, elongation, formation of dried tissues in plants and production of plant growth regulators (López-Reyes 2017; Shi et al. 2018; Zhang et al. 2019; Khan et al. 2020). Similarly, Laslo et al. (2012) reported that the rapid colonization of maize plant roots due to the production of siderophores by Pseudomonas strains stimulates plant growth and is often due to the reduction in the fungal population in the roots (Penyalver et al. 2001).

Under artificially infested field conditions, grains treated with rhizobacterial strains significantly decreased disease incidence and improved yield and yield component of maize during the 2018 and 2019 seasons. In the current study, antioxidant enzymes' activity (CAT, POX and PPO) significantly improved in plants exposed to inoculation treatments with $B$. subtilis and $P$. koreensis either alone or in combination, which in turn reflected in the reduced disease incidence. We observed that plants inoculated with dual inoculation showed higher ( 3 and 2.5 fold) CAT activities than control plants in the 2018 and 2019 seasons, respectively, at 60 days after sowing (Fig. 4). These increases in CAT activity were associated with higher growth rates of the most infective fungus. Therefore, CAT plays a vital role in the regulation of intraradical fungal growth. Also, surveying with $\mathrm{H}_{2} \mathrm{O}_{2}$ by CAT is an effective mechanism for mitigating plant defense responses (Wu et al. 1997). These findings are supported by those reported for other crops grown under infested soil conditions such as maize (Kumar et al. 2009), eggplant (Altinok et al. 2013), tomato (Chandrasekaran and Chun 2016), cotton (Selim et al. 2017), soybean (Zilli et al. 2018) and potato (Bagy et al. 2019).

A similar trend was also observed in the activities of POX. The higher activity of peroxidase was recorded by the application B. subtilis and P. koreensis (T5) which showed an increase rate recorded 55-60\% during the two growing seasons (Fig. 4). Vidhyasekaran (1997) showed that peroxidase enzyme may be involved in the regulation of plant cell elongation, polysaccharide cross-linking, phenol oxidation and IAA oxidation as well as associated with disease resistance in plants and increases in host plants following pathogen infection (Scott-craiz et al. 1995). Several previous researches confirmed that addition of PGPR to plants induces the activity of POX enzyme and, therefore, enhances the plant's disease resistance (Ramamoorthy et al. 2001; Paul and Sarma 2005; Renuka et al. 2009; Kaur et al. 2017; Zilli et al. 2018; Bagy et al. 2019). In the case of PPO activity, we observed that maize plants inoculated with single inoculation showed 2.75- and 3.14-fold higher activity for T3 (grains inoculated with B. subtilis) and 5.5- and 4.75-fold for T4 (grains inoculated with P. koreensis), whereas dual inoculation for T5 (inoculated with a mixture of $B$. subtilis and $P$. koreensis) recorded 7- and 4.75-fold in the 2018 and 2019 seasons, respectively (Fig. 4). It is known that the process of oxidizing phenols to quinones substances, which are toxic to pathogens due to PPO enzyme. Also, PPO enzyme can function in the following ways: (1) quinines substances produced by PPO may alkylate essential amino acids which decrease plant nutritional quality, (2) sometimes, and through redox cycling, quinones may produce oxidative stress in the gut lumen and (3) from phenolic oxidation, quinone substances produced may be absorbed and have toxic effects on herbivores (Helmi and Mohamed 2016). Chandrasekaran and Chun (2016) indicated that $B$. subtilis CBR05 treatment showed a significant increase in PPO activity in the leaves of tomato infested with soft rot disease (Erwinia carotovora subsp. carotovora). Also, PPO enzyme activities have been well established by Kaur et al. (2017). They found that infested wheat plants with aphid showed a significant increase in PPO activity (1.4fold) at 28 days after emergence (DAE) as compared to the respective uninfested plants. Also, the content of photosynthetic pigments showed a significant increase under the combined inoculation with B. subtilis and P. koreensis (Fig. 4). In this regard, the severity of late wilt disease is associated with chlorophyll catabolism; therefore, the pathogen causes chlorophyll deterioration and organelle damage and cell death (Kariola et al., 2005; Bagy et al. 2019). The inoculation treatments with B. subtilis and $P$. koreensis individually or in combinations may induce disease resistance through photosynthetic pigment restoration to reduce disease development. Our results are in agreement with the findings of Borkar and Yumlembam (2016) and El-Shabrawy and Shehata (2018), concerning the efficiency of inoculation treatments on maize late wilt disease and stem histological differences (Figs. 5, 6). Treatment with a mixture of $B$. subtilis and P. koreensis (T5) gave the highest effect in reducing infection and increase in thickness of the sclerenchymatous sheath layer surrounding the vascular bundles. These results may be due to the production of siderophores, non-volatile diffusible metabolites which are related to significant inhibition and biocontrol of the pathogen (El-Mehalowy et al. 2004; Selim et al. 2017; Bagy et al. 2019). Also, mycelial growth was clearly found in the bundles of stems in 85 days maize plants infected with $C$. maydis (control treatments). On the contrary, all inoculation treatments showed more layers of sclerenchymatous cells surrounding the xylem vessels. These findings are supported by (Kumar et al. 2009; Boon et al. 2012; Hajiboland et al. 2012; Ghazy et al. 2017). For yield and yield parameters, inoculation treatments either alone or in combination showed significant influence compared to control (Table 4). These increase in yield due to improve the availability of essential nutrients, 
production of phytohormones, improved Fe availability through chelating soil iron by production of siderophores and enhanced plant resistance system. These results corroborate with those of ,, , and ).

\section{Conclusion}

Our findings indicate that B. subtilis MF497446 and $P$. koreensis MG209738 were found to be the most effective PGPRs as shown by qualitative and quantitative assays for siderophore production and individually or in combination inoculation condition, leading to induce the disease resistance of late wilt caused by $C$. maydis in maize plant and improvement of growth promotion and yield. Further investigations are required to study the interactions at the level of gene related to siderophore production in PGPR, pathogenic fungi or host plant.

Acknowledgements We thank all staff members and colleagues in The Bacteriology Research Laboratory and Maize and Sugar Crops Dis. Dept., Sakha Agricultural Research Station, Kafrelsheikh, Egypt, for their valuable cooperation which made completion of this work possible. Also, this work is supported in cooperation between SWERI, ARC, and Egyptian maize breeding programs, PPRI, ARC, Egypt.

Authors contributions SE conceived of and designed the study. SE and $\mathrm{NG}$ analyzed and interpreted the data. All authors gave final approval of the version to be published.

\section{Compliance with ethical standard}

Conflict of interest The authors declare that they have no conflict of interest.

\section{References}

Abd El-Ghani HS (1987) Studies on stalk-rot disease of corn in Egypt. $\mathrm{Ph}$. D. Thesis, Faculty of Agriculture, Ain Shams University, Cairo, Egypt

Aebi H (1984) Catalase in vitro. Methods Enzymol 105:121-126

Ali I, Sultan T, Subhan F, Haleem KS, Sultana N, Tauseef I (2018) PGPRs of plum (Prunus domestica) rhizosphere enhance plant growth and antagonise fungal activity in vitro Acta Agriculturae Scandinavica, Section B. Soil Plant Sci 68(4):367-378

Altinok HH, Dikilitas M, Yildiz HN (2013) Potential of Pseudomonas and Bacillus isolates as biocontrol agents against fusarium wilt of eggplant. Biotechnol Biotechnol Equip 27(4):3952-3958

Anonymous (1957) Manual of microbiological methods. McGraw Hill, New York, p 127

Arnow E (1937) Colorimetric determination of the components of 3,4-dihydroxyphenylalanine-tyrosine mixtures. J Biol Chem 118:531-537

Ashour AM, Sabet KA, El-Shabrawy EM, Alhanshoul AM (2013) Control of maize late wilt and enhancing plant growth parameters using rhizobacteria and organic compounds. Egypt J Phytopath 41(2):187-207
Bagy HMK, Hassan EA, Nafady NA, Dawood MF (2019) Efficacy of arbuscular mycorrhizal fungi and endophytic strain Epicoccum nigrum ASU11 as biocontrol agents against blackleg disease of potato caused by bacterial strain Pectobacterium carotovora subsp. atrosepticum PHY7. Biol Control 134:103-113

Balagurunathan R, Radhakrishnan M (2007) Microbial Siderophores-gateway for iron removal. Envis Centre Newsletter. https ://www.envismadrasuniv.org/n120007articles\%20sidephore.html

Bashan Y, De-Bashan LE, Prabhu SR, Hernandez JP (2014) Advances in plant growth-promoting bacterial inoculant technology: formulations and practical perspectives (19982013) (a marschner review). Plant Soil 378:1-33. https://doi. org/10.1007/s11104-013-1956-x

Becker JO, Cook RJ (1988) Role of siderophores in suppression of Pythium species and production of increased growth response of wheat by fluorescent pseudomonads. Phytopathol 78:778-782

Beneduzi A, Ambrosini A, Passaglia LM (2012) Plant growth-promoting rhizobacteria (PGPR): their potential as antagonists and biocontrol agents. Genet Mol Biol 35:1044-1051

Boon EJMC, Struik PC, Engels FM, Cone JW (2012) Stem characteristics of two forage maize (Zea mays L.) cultivars varying in whole plant digestibility. IV. Changes during the growing season in anatomy and chemical composition in relation to fermentation characteristics of a lower internode. NJAS Wageningen J Life Sci 59(1-2):13-23

Borkar SG, Yumlembam RA (2016) Bacterial diseases of crop plants. CRC Press, Boca Raton

Chandrasekaran M, Chun SC (2016) Expression of PR-protein genes and induction of defense-related enzymes by Bacillus subtilis CBR05 in tomato (Solanum lycopersicum) plants challenged with Erwinia carotovora subsp. carotovora. Biosci Biotechnol Biochem 80(11):2277-2283

Cśaky TZ (1948) On the estimation of bound hydroxylamine in biological materials. Acta Chem Scand 2:450-454

Duncan BD (1955) Multiple ranges and multiple F. test. Biometrics $11: 1-42$

Ebrahim EMT (2010) Relation of fluorescent bacteria in controlling some root diseases of sugar beet. Ph.D. Thesis, Faculty of Science, Bani-Seuf University, Egypt, 195p

El-Mehalowy AA, Hassanein NM, Khater HM, Daram El-Din EA, Youssef YA (2004) Influence of maize root colonization by Rhizosphere actinomycetes and yeast fungi on plant growth and on the biological control of late wilt disease. Int J Agric Biol 6:599-605

El-Nahrawy S, Elhawat N, Alshaal T (2019) Biochemical traits of Bacillus subtilis MF497446: its implications on the development of cowpea under cadmium stress and ensuring food safety. Ecotoxicol Environ Saf 180:384-395

El-Shabrawy ES, Shehata H (2018) Controlling maize late-wilt and enhancing plant salinity tolerance by some rhizobacterial strains. Egypt J Phytopathol 46(1):235-255

El-Shafey HA, Claflin LE (1999) Late wilt. In: White DG (ed) Compendium of corn diseases, 3rd edn. The American Phytopathological Society, St. Paul, pp 43-44

Elshahawy IE, El-Sayed AEKB (2018) Maximizing the efficacy of Trichoderma to control Cephalosporium maydis, causing maize late wilt disease, using freshwater microalgae extracts. Egypt $\mathbf{J}$ Biol Pest Control 28(1):48

FAOSTAT (2018) Food and Agriculture Organization of the United Nations Statistics Division. https://www.fao.org/faostat/ en/\#data/QC.

Ferreira JHS, Matthee FN, Thomas AC (1991) Biological control of Eutypa lota on grapevine by an antagonistic strain of Bacillus subtilis. Phytopathology 81:281-283

Ghavami N, Alikhani HA, Pourbabaee AA, Besharati H (2016) Study the effects of siderophore-producing bacteria on zinc and 
phosphorous nutrition of canola and maize plants. Commun Soil Sci Plant Anal 47(12):1517-1527

Ghazy NA, El-Gremi S, Belal ES (2017) Chemical and histological differences of maize (Zea mays L.) responsive to Harpophora maydis infection. Environ Biodivers Soil Secur 1:191-201

Grobelak A, Hiller J (2017) Bacterial siderophores promote plant growth: screening of catechol and hydroxamate siderophores. Int J Phytorem 19(9):825-833

Hajiboland R, Farhanghi F, Aliasgharpour M (2012) Morphological and anatomical modifications in leaf, stem and roots of four plant species under boron deficiency conditions. In: Anales de Biología, vol 34, pp 15-29. Servicio de Publicaciones de la Universidad de Murcia.

Hammerschmidt R, Nuckles EM, Kuć J (1982) Association of enhanced peroxidase activity with induced systemic resistance of cucumber to Colletotrichum lagenarium. Physiol Plant Pathol 20(1):73-82

Hamza AM, El-Kot GA, El-Moghazy S (2013) Non-traditional methods for controlling maize late wilt disease caused by Cephalosporium maydis. Egypt J Biological Pest Cont 23(1):87-93

Helmi A, Mohamed HI (2016) Biochemical and ultrastructural changes of some tomato cultivars after infestation with Aphis gossypii Glover (Hemiptera: Aphididae) at Qalyubiyah. Egypt Gesunde Pflanzen 68:41-50

Höfte M, Seong KY, Jurkevitch E, Verstraete W (1991) Pyoverdin production by the plant growth beneficial Pseudomonas strain 7NSK 2: Ecological significance in soil. Plant Soil 130(1-2):249-257

Jacobsen BJ, Zidack NK, Larson BJ (2004) The role of Bacillus-based biological control agents in integrated pest management systems: plant diseases. Phytopathology 94:1272-1275

Kariola T, Brader G, Li J, Palva ET (2005) Chlorophyllase 1, a damage control enzyme, affects the balance between defense pathways in plants. Plant Cell 17(1):282-294

Kaur H, Salh PK, Singh B (2017) Role of defense enzymes and phenolics in resistance of wheat crop (Triticum aestivum L.) towards aphid complex. J Plant Interact 12(1):304-311

Khan MS, Gao J, Chen X, Zhang M, Yang F, Du Y, Zhang X (2020) Isolation and characterization of plant growth-promoting endophytic bacteria Paenibacillus polymyxa SK1 from Lilium lancifolium. Bio Med Res Int 10:305

Kim WG, Weon HY, Lee SY (2008) In vitro antagonistic effects of Bacilli isolates against four soilborne plant pathogenic fungi. Plant Pathol J 24(1):52-57

Kumar M, Yadav V, Tuteja N, Johri AK (2009) Antioxidant enzyme activities in maize plants colonized with Piriformospora indica. Microbiology 155(3):780-790

Labib HA, Abdel-Rahim MF, Salem A, Abdel-Fattah A (1975) A new maize hybrid seed resistant to late wilt disease caused by Cephalosporium maydis. Agric Res Rev 53:1-4

Lacava PT, Silva-stenico ME, Araújo WL, Valéria A, Simionato C (2008) Detection of siderophores in endophytic bacteria Methylobacterium spp. Pescuei Agropceu Bras 43:521-528

Larkin RP (2020) Biological control of soilborne diseases in organic potato production using hypovirulent strains of Rhizoctonia solani. Biol Agric Hortic 36:1-11

López-Reyes L, Carcaño-Montiel MG, Lilia TL, Medina-de la Rosa G, Armando THR (2017) Antifungal and growth-promoting activity of Azospirillum brasilense in Zea mays L. ssp. mexicana. Arch Phytopathol Plant Protect 50(13-14):727-743

Malik CP, Singh MB (1980) In: Plant enzymology and histoenzymology, pp 54-56. Kalyani Publishers. Delhi

Mavrodi OV, Gardener BB, Mavrodi DV, Bonsall RF, Weller DM, Thomashow LS (2001) Genetic diversity of 2,4- diacetylphloroglucinol producing fluorescent Pseudomonas spp. Phytopathology 91:35-43
Mohammed AF, Oloyede AR, Odeseye AO (2020) Biological control of bacterial wilt of tomato caused by Ralstonia solanacearum using Pseudomonas species isolated from the rhizosphere of tomato plants. Arch Phytopathol Plant Protect 53(1-2):1-16

Mousa NA, Siaguru P, Wiryowidagdo S, Wagih ME (2007) Evaluation and selection of elite clonal genotypes of the sweet crop licorice (Glycyrrhiza glabra) in a new environment. Sugar Technol 9:83-94

Nawar LS (2007) Pathological and rhizospherical studies on rootrot disease of squash in Saudi Arabia and its control. African J Biotechnol 6(3):219-226

Nuss ET, Tanumihardjo SA (2010) Maize: a paramount staple crop in the context of global nutrition. Compr Rev Food Sci 9:417-436. https://doi.org/10.1111/j.1541-4337.2010.00117.x

Omara AED, Hauka F, Afify A, Nour El-Din M, Kassem M (2017) The role of some PGPR strains to biocontrol Rhizoctonia solani in soybean and enhancement the growth dynamics and seed yield. Environ Biodiv Soil Secur 1:47-59

Omara AED, Nour El-Din M, Hauka F, Hafez A, El-Nahrawy S, Ghazi A, Fusco V (2018) Suppression of Rhizoctonia solani Damping-off in Soybean (Glycine max L.) by Plant Growth Promoting Rhizobacteria Strains. Environment, Biodiversity and Soil Security 2:39-49

Oswald A (2010) Evaluating soil rhizobacteria for their ability to enhance plant growth and tuber yield in potato. Ann Appl Biol 157:259-271

Paul D, Sarma YR (2005) Pseudomonas fluorescens mediated systemic resistance in black pepper (Piper nigrum L.) is driven through an elevated synthesis of defence enzymes. Archives of phytopathology and Plant protection 38(2): 139-149.

Penyalver R, Oger P, Lopez MM, Farrand SK (2001) Iron-binding compounds from Agrobacterium spp.: biological control strain Agrobacterium rhizogenes K84 produces a hydroxamate siderophore. Appl Environmen Microbiol 67:654-664

Ramamoorthy V, Viswanathan R, Raguchander T, Prakasam V, Samiyappan R (2001) Induction of systemic resistance by plant growth promoting rhizobacteria in crop plants against pests and diseases. Crop Prot 20(1):1-11

Rajkumar M, Ae N, Prasad MNV, Freitas H (2010) Potential of siderophore-producing bacteria for improving heavy metal phytoextraction. Trends Biotechnol 28(3):142-149

Renuka R, Prakasam V, Sundravadana S (2009) Studies on the activity of defense enzymes against Alternaria Chlamydospora the incitant of leaf blight of chrysanthemum (Dendranthema grandiflorum Tzelvev). Arch Phytopathol Plant Protect 42(12):1165-1171

Sabet KA, Samra AS, Mansour IM (1970) Saprophytic behavior of Cephalosporium maydis and C. acremonium. Ann Appl Biol 66:265-271

Sammauria R, Kumawat S, Kumawat P, Singh J, Jatwa TK (2020) Microbial inoculants: potential tool for sustainability of agricultural production systems. Arch Microbiol 202:1-17

Samra AS, Sabet KA, Hingorani MK (1963) Late wilt disease of maize caused by Cephalosporium maydis. Phytopath 53:402-406

Sandani HBP, Ranathunge NP, Lakshman PLN, Weerakoon WMW (2019) Biocontrol potential of five Burkholderia and Pseudomonas strains against Colletotrichum truncatum infecting chilli pepper. Biocontrol Sci Tech 29(8):727-745

Sass JE (1961) Elements Of Botanical Microtechnique. McGraw-Hill Book Co., Inc., New York. (C.F.Abd El-Ghani, Haifa, S., 1987)

Schwyn B, Neilands JB (1987) Universal chemical assay for the detection and determination of siderophores. Anal Biochem 160:47-56. https://doi.org/10.1016/0003-2697(87)90612-9

Scott-craiz JS, Kerby KB, Stein BD, Somerville SC (1995) Expression of an extracellular peroxidase that is induced in barely (Hordeum 
vulgare) by the powdery mildew pathogen (Erysiphe graminis f.sp hordei). Physiol Mol Plant Pathol 47:407-418

Selim HM, Gomaa NM, Essa AM (2017) Application of endophytic bacteria for the biocontrol of Rhizoctonia solani (Cantharellales: ceratobasidiaceae) damping-off disease in cotton seedlings. Biocontrol Sci Technol 27(1):81-95

Sheng M, Jia H, Zhang G, Zeng L, Zhang T, Long Y, Liu H (2020) Siderophore production by rhizosphere biological control bacteria Brevibacillus brevis GZDF3 of Pinellia ternata and its antifungal effects on Candida albicans. J Microbiol Biotechnol 30(5):689-699

Shi L, Nwet TT, Ge B, Zhao W, Liu B, Cui H, Zhang K (2018) Antifungal and plant growth-promoting activities of Streptomyces roseoflavus strain NKZ-259. Biol Control 125:57-64

Shivakumar B (2007) Biocontrol potential and plant growth promotional activity of fluorescent pseudomonads of western ghats (Doctoral dissertation, UAS, Dharwad)

Sinha AK, Parli BV (2020) Siderophore production by bacteria isolated from mangrove sediments: a microcosm study. J Exp Mar Biol Ecol 524:151290

Subagio A, Foster HL (2003) Proceedings of the MAPPS Conference: implications of Ganoderma disease on loss in stand and yield production of oil palm in North Sumatra, Kuala Lumpur, Malaysia

Suryakala D, Maheshwaridevi PV, Lakshmi KV (2004) Chemical characterization and in vitro antibiosis of siderophores of rhizosphere fluorescent pseudomonads. Indian J Microbiol 44:105-108

Thomashow LS, Weller DM (1991) Role of antibiotics and siderophores in biocontrol of take-all disease of wheat. The rhizosphere and plant growth. Springer, Netherlands, pp 245-251

Vidhyasekaran P (1997) Fungal pathogenisis in plants and crops. In: Molecular biology and host defense mechanisms, p 553. Marcel Dekker, New York

Wu GS, Shortt BJ, Lawrence EB, Leon J, Fitzsimmons KC, Levine EB, Raskin I, Shah DM (1997) Activation of host defense mechanisms by elevated production of $\mathrm{H}_{2} \mathrm{O}_{2}$ in transgenic plants. Plant Physiol 115:427-435

Yang MM, Mavrodi DV, Mavrodi OV, Bonsall RF, Parejko JA, Paulitz TC, Thomashow LS, Yang HT, Weller DM, Guo JH (2011) Biological control of take-all by fluorescent Pseudomonas spp. from Chinese wheat fields. Phytopathology 101(14):81-91. https://doi. org/10.1094/PHYTO-04-11-0096

Yassin MA (2000) Diversity in isolates of late wilt of maize in Egypt. M. Sc. Thesis, Faculty of Agriculture, Cairo University, Egypt

Zeller KA, Ismael AS, El-Assiuty EM, Fahmy ZM, Bekheet FM, Leslie JF (2002) Relative competitiveness and virulence of four clonal lineages of Cephalosporium maydis from Egypt toward greenhouse-grown maize. Plant Dis 86:373-378

Zhang J, Fu Y, Xiang W (2019) Antifungal, plant growth-promoting and genomic properties of an endophytic actinobacterium Streptomyces sp. NEAU-S7GS2. Front Microbiol 10:2077

Zhao QY, Xu SJ, Zhang WS, Zhang Z, Yao Z, Chen XP, Zou CQ (2020) Identifying key drivers for geospatial variation of grain micronutrient concentrations in major maize production regions of China. Environ Pollut 266:115114

Zilli CG, Carmona MA, Simonetti E, Santa-Cruz DM, Yannarelli GG, Balestrasse KB (2018) Biocontrol of Macrophomina phaseolina (Tassi) Goid: differential production of $\mathrm{H}_{2} \mathrm{O}_{2}$ and in the relationship pathogen-PGPR in soybean seedling. Biocontrol Sci Technol 28(4):416-422

Publisher's Note Springer Nature remains neutral with regard to jurisdictional claims in published maps and institutional affiliations. 